\title{
世界の紙パルプ産業の傾向
}

( I )

既にしばしばウオッヘンブラット誌の経済欄に抢い て製紙工業は各国の国民絓済の消長を忠実に反映する 工業に属することを指摘した。紙というものは文化的 関係方面と余りに密接なつながりがあるから，製紙産 業の独立発展がここに源を発することも考兄られよう。 元より, 需給の間に宕干の時期的ズレの度々あること も紙市場では確認されている。

然し, 大ざっぱに見て, 長期見透しから, 紙の生産 の発展的傾向とい5 ものは, 一般経済活動, 特飞産業 活動の発展曲線とよく一致を示す。

世界の製絓産業のすがたは北米及び西欧の大生産地 域によって強い翰郭を浮出たせていることは当然であ るが，重要ならざる生產地域るまた，幾分の相迲はあ るにしてる, 現在の大製紙国の発展に参加しているこ とは易く了解される。

\section{( II)}

広範な計数資料に基づき傎重に碩感した後，1954度 の紙パプ生産に関係ある甘界各国の合計産額を見る そ
化学パルテ゚
GP
約 2700 万 t
紙及び板紙
$1600 "$
$5200 "$

大ざっぱに計算して，1/3は欧州，2/3は游外諸国で生 産された。この関係は19:0年以来化学パルブ及びG P に打いて欧州諸国にとって立だ若下不利に推移してい る一方，欧州の紙及び板紙の尘産は比較的算って来た。 (第 1 表参源)

注川に值与るは，欧州以外の諸国の化学パルプ生産 は1950年来欧州より著しく増加せるに反し，G P も紙
及び板紙の生産る比較的劣っている。これは近年にお ける北米パルプ工業の継続的桩張が確がとの原因を なす。この発展の根源は一方において米国製紙工業の 偉大な躍進（紙及び板紙の生㦃は 1950 年来 2210 万 $\mathrm{t}$

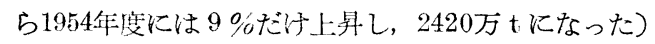
のためにもよるが，乙かし完全合成物質の前例なき飛 蹋にも拘らずセルローズ系の各種の化学紻維市場がな 敃繁栄を続けていることに帰せられる。米国製紙工業 にとりて，パルプ輸入の突破口が徐々に埋められる事 は組織的にも，效果的にも重視さるべきであろう。早 ルプの輸入は 1950 年来 190 万七から 160 万 t 亿減退し たのに，輸出は 85000 t から 392000 七一上界した。これ 等諸国の超過量は次の数字からる明示される: 合夏国 及びカナダは1950年並びに1954年度の何れに括いてる， パルプの世界生産高の約 $\% 10$ 占め，GPでは 1950 年 度 $62 \% ， 19 \% 4$ 年度 $54 \%$ であったが，紙及び板紙の占め る。社とれぞれ66吕及び $60 \%$ であった。1950一54年迄 に兩国のパルブ，GP收び紙と板紙の生産高はそれぞ れ23\%，15\%及び20\%だけ增加した。（第 2 表参照）

\section{第2 表}

欧州以外の国のパルプ, G P, 䋊及び板紙生産高 1950及び1954年度 $(1000 t *)$

\begin{tabular}{|c|c|c|c|c|c|c|}
\hline & \multicolumn{2}{|c|}{ 化学バルプ } & \multicolumn{2}{|c|}{$\mathrm{G}-\mathrm{P}$} & \multicolumn{2}{|c|}{ 䄳及心板䋏。 } \\
\hline & 1950 & 1954 & 1950 & 1954 & 1950 & 1954 \\
\hline 北 & 12,982 & 15,968 & 8,172 & 9,407 & 28,287 & 31,109 \\
\hline ○の他諸国 & 648 & 1,544 & 589 & 975 & 2,183 & 4,024 \\
\hline 炊州外諸国合計 & 13,630 & 17,512 & $8,761$. & 10,382 & 30,470 & $35,1.33$ \\
\hline
\end{tabular}

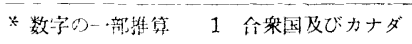

\section{(1)}

然るに，第 2 表に明らかな通りその他の欧州外諸国 に和いても，進步が起りつつある。
第1表 パルプ，G P , 紙及び板紙の世界生座高

$$
\text { 1950及び1954(1000 t*) }
$$

\begin{tabular}{|c|c|c|c|c|c|c|c|c|c|}
\hline & 化 & 学 & 70 & G & & $P$ & 紙 & 及び板 & 林 \\
\hline & 1950 & 1954 & 上鼠率 & 1950 & 1954 & 上萛率 & 1950 & 1954 & 上算乘 \\
\hline 欧 州 & 7,715 & 9,636 & 25 & 4,533 & 5,762 & 27 & 12,765 & 16,835 & 32 \\
\hline 欧州以外 & 13,630 & 17,512 & 29 & 8,761 & 10,382 & 19 & 30,470 & 35,133 & 15 \\
\hline 世织合部 & 21,345 & 27.148 & 27 & 13,294 & 16,144 & 22 & 43,235 & 51,968 & 20 \\
\hline
\end{tabular}

合衆国及びカナダ以外の海外諸国 は，大製絓国の間に伍しての役割は 比較的重贾ではないが, 注月に值す る発展をなしている。

これら諸国も1950年度に比し, 1954年度にはパルプにおいて 2 倍以 上，G P，紙及び板絓において約 2 倍になっている。この際特に日本の 
指導的役割を顧虑すべきである。

日本は, 著しい戦禍にも拘らず, 就中戦前における 㮖太，満州及び台湾の資源の大部分を䔽尽してしまっ たに拘らず, 1950年以来化学パルプの生産は $162 \%$ 紙 及び板紙の生産は $120 \%$ 增加するに至った国である。 これ等諸国の1954年度全生産高に対し，日本の占める 割合はパルプは2/3，G P は1 $/ 2$ 強, 紙及び板紙は1 $/ 2$ 蒻で あった。

これらの欧州圈外の諸国に拉いては，同椂に発展が 活發に進んでいるが, 自ら相違がある。或いはアルゼ ンチン，ブラジル及び嫁州におけるが如くパルプ及び G P の資源が紙の生産高より著しく豊富の所もあれば， 或いは例えば南アフリカ及びメキシュに見らるる如く あらゆる面で均斉がとれ生産的に相互調和された経過 をとってる所るあった。新興国家の中には近年次第に 相当の建設資金を以て着工するもの，生産計画中のる のも少くない。例えばニュージーランドはパルプを， モロッコ及びアルゼリアはパルプ及び紙, ポルトガル 領西アフリカ, ベルギー領コンゴー, イスラェル, イ ラン, インド及びパキスタンその他多数の国は, 国産 原料を基礎にして自国の紙の調達を幅広い基盤の上に 確立したく考㝋ている。然し，すべてこれ等の諸国の 製紙産業の昖張上資金調達に頗る障害がある。

\section{(IV)}

欧州諸国をその政治情勢に堡って西部及び東部に分 けると, 一一東部地区の見積を内輪に見て一-1954年 度の西部欧州の製紙工菜はパルプ，G P, 紙及び板紙 生産高に和いて, それぞれ 4 分の 3 蔃, 4 分の 3 彁及 び約10分の 8 を占めた。

されば, この優勢の状態は西部欧州の場合, 少くと も理論的には無尽藏に見え, 然し未だ斧鈛を加えざる 原料資源一パルプ材一をるつソ連を加えてる問題でな いという明白な事実に立脚している。

しかし，斯業の一般的躍進は西部欧州に限られたこ とではない。1950-1954年間の西部欧州のパルプ， G P 及び紙の生産增加は平均約 $30 \%$ と見積られるに反し， 興味ある事は東部欧州においては增率がパルプ及び $\mathrm{G}$ Pの17\%及び45\%市るに対し，紙及び板紙の生産高は 遙かにこれを淩駕し, 增率60\%であった。この一般情 勢はパルプ及紙間の現在の平衡関係を示すのみか, 更 にこれ等諸国の特殊の原料難に関し何等か結論を暗示 するものであろら。一ーその結論の方向とは先ず次の 如きものと思われる, 即ら木材の欠乏, 従ってパルプ 及びG P の欠乏は製紙工業をして一層強く故紙導入を 必要ならしめる。ここに補足したい事は, 東部の国家
群は西部諸国から僅少の輸入の余地しか持たないこと で，西部諸国に拈ける原料（パルプ及びG P) 供給は 持続的に改善出来よ5。しかしこれに対し，西部欧州 へ広範のパルプ及び紙供給を求めんとしても，それに 対する王迫は当分政治的に操作されるである5。

\section{茅 3 表}

欧州のパルプ, GP，紙及び板紙生産高! 1950及び1954, $1000 \mathrm{t}$ *

\begin{tabular}{|c|c|c|c|c|c|}
\hline & & パプ & & $\mathrm{P}$ & 社及び板紙 \\
\hline & & $1950-195 \overline{4}$ & $1950^{-}$ & 1954 & 1950 \\
\hline 西欧諸国 & 1 & $5,950 \quad 7,569$ & 3,482 & 4,237 & $10,926 \quad 13,909$ \\
\hline 東欧藸国 & 2 & $1,765 \quad 2,067$ & 1,051 & 1,525 & $1,839 \quad 2,926$ \\
\hline 欧州合計 & & $7,715 \quad 9,636$ & 4,533 & 5,762 & $12,76516,835$ \\
\hline
\end{tabular}

1. 西欧にフインランド及び S BZを含まず；2，ソ連，ブルガリ フ、ポーランド (東热を含む), ルーマニア,チェコスロバキア, ヘンガリー; *西炏に対しては一部推算, 東欧に対しては强く 見込んだ。

西部欧州において，戦禍を最も強く受けた国々の踓 進が特に印象的に浮び上った。かくて西独，仏，伊， 和，ノルウェー及び墺の製紙工業は白及び英における よりも1950年来一段と発展した。すべてこれらの諸国 はどちらかといえばパルプ工業よりも紙及び板紙工業 の発展の方が比較的花々しい。フインランドは特殊の 発展を遂げたが，スエーデン，スイス及びスペインの 媻紙工業す同椂であるが，西欧の生産向上性運動に対 する関与の度合は国々により自ら強弱がある。（第3 表参照)

\section{( $V$ )}

欧州経済調整局（OE E C）に属する西欧諸国に対 し, 最近 1955 年上半期の成縜が公表された。1950年上 期と比較すると，構成上に著しい差が認められた。 (第 4 表参照)

\section{第 4 表}

欧州経済調整局 (OEE C) 所属国のパ ルプ，G P，紙及び板紙の供給昌 : 1950 年上期及び1955年上期, $1000 \mathrm{t}$ 単位

\begin{tabular}{|c|c|c|c|c|c|c|}
\hline & \multicolumn{2}{|c|}{ パルプ 1} & \multirow{2}{*}{$\begin{array}{c}\mathrm{G} \\
1950 \overline{5} \\
5 . \quad \text { 年 } \\
\end{array}$} & \multirow{2}{*}{$\begin{array}{c}\text { P } \\
1955 \text { 年 } \\
\text { 上. 期 }\end{array}$} & \multicolumn{2}{|c|}{ 緍及び板紙 } \\
\hline & $\begin{array}{l}1950 \text { 年 } \\
\mathrm{t}: \text { 期 }\end{array}$ & $\begin{array}{l}\text { 1955年 } \\
\text { 上 期 }\end{array}$ & & & $\begin{array}{l}\text { 1950年 } \\
\text { 上 期 }\end{array}$ & $\begin{array}{l}\text { 1955年 } \\
\text { 上 期 }\end{array}$ \\
\hline 生産高 & 1,701 & 2,296 & 1,158 & 1,572 & 4,463 & 6,450 \\
\hline $\begin{array}{l}\text { 十非OEEC } \\
\text { 所属国より } \\
\text { の桶入 }\end{array}$ & 337 & 610 & 77 & 91 & 149 & 493 \\
\hline -" & 329 & $\begin{array}{r}185 \\
-\ldots\end{array}$ & 14 & 13 & 431 & 384 \\
\hline 供給 量 & 1,709 & 2,721 & 1,221 . & 1,650 & 4,181 & 6,559 \\
\hline
\end{tabular}

* 墺, 白、和，丁，仏、希、フイルランド，伊，ノルウエー、瑞， スイス，英，西独，1．ワラを含む製紙用バルプのみ，本表のH 所: OEEC, Pulp and Paper Committee, Nov. 1955

本表を見ると，先ず第一に1950年来あらゆる段階に おいて生産は著増している。即ちパルプ及びGPの生 
産がそれぞれ35\%及び36\%だけ増加したに反し紙及び 板紙の生産は $45 \%$ \%た増加した。しかるに, 輸入の発 展の示す通り, 製紙工業の大努力にも拘らず, 長く堰 止められていた紙の需用の増加と步調を合わせるには 生産は不充分である。非西欧同盟国家, 主としてフィ ンランド及び北米からのパルプ輸入は，1950 年来パ ルプにおいて約 2 倍, 紙において 3 倍以上增加した。 一方調整局所属国圈からの輸出は大ざっぱに見てパル プにおいて著しく，紙及び板紙に拉いて若干減退した から，これらの国家群の供給に対し本圈の生産挔大に マッチする以上遙か多量のパルプ及び紙を自由に処理 し得た。されば,これら諸国の消費の向上:は輸入関係 の溸増で購ひ得ることは明白である。1950年上期のパ ルプ供給に拉ける輸入割合は13\%なるに，1955年上期 には既に17\%に達した，紙及び板紙では同期間におけ る輸入率は $4 \%$ から $8 \%$ であった。最も著しい增加は クラフト紙及び同板紙の 5 倍以上（1950 年上期来）,

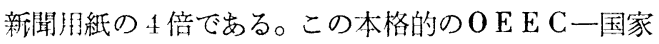
の外国貿易は恐らくい打る「国内商業」即ち $\mathrm{OEE}$ C諸国間の物資交易とは区別せらるべきであろう，本 交易は一- 新聞用紙は例外として一-1955年上期には 非西欧同盟国との外国貿易よりは非常に強くあった。 例えば紙及び板紙の場合，1950年来国内輸入の増加は 67\%と解された。

西欧のこれまでのテンポで増加し行く紙の需用がそ れに相応する輸入量の增加を導くか不かを予测するこ とは容易の策でないことは，最近追加された各国の製 造設備の生産能力が，広告された完全雇侓にも拘らず, 真に技術的最上限或いは経済的至上限に利用されるか 否か定かでないからである。多分に能力に若下の遊び があるか, 或いは連続操業の採用又は合理化, 何れに よっても少くとも調整を要しょう。結局, 西欧の将来 の紙の消費の発展は種々の要因に支配されることであ ろう, 就中一般の経済的進步によること勿論である。 しかし, 各国亚びに各国間に現存する紙消費の節約規 制の徹廃もこの場合重大の關心事であろう。

(ウオッヘンブラット誌上のエミール・フイッシャ 一博士の符稿の要旨——佐藤)

\section{ト 一 ル油賞}

米国パルプ化学協会は本日 $\$ 500, \$ 350, \$ 100$ の 賞金を Robert S. Aries 及 Melvin Wolkstein (the Polytechnic Institute of Brooklyn), Jacobus Rinse (Chemical Research Associates), Pauro Kajanne (the Institute of Technology at Helsinki, Finland) へ贈ると発表した。

最初の二つの賞金は，本日トール油課の集まりの後 の午䬸の席で, Arizona Chemicals Company 副社長, the Tall Oil Division of the Pulp Chemicals Association の会長である Albert Scharwachter によつて, 獲得者に渡された。

賞を得た論文は，昨年10月に終った賞金コンテスト に応じてトール油課に提出された論文の中から選ばれ たものである。裁定に対しては, 幸運にも化学操作工 業の 3 人の優れた専門家, Walter J Murphy (アメ リカ化学協会編集長), Hery F. Dayne (フロリダ大 学), 及 Francis Scofield (National Paint, Varnisch and Lacqer 協会) の骨折りを得た。

\$500 の一等賞はグリセリンとトール油のエステル 化に関する Robert S. Aries 及 Melvin Walkstein の共同研究に対して与えられた。エステル化の最良条 件, 触媒の効果, 及トール油の脂肪酸及び樹脂酸の働 きの相違に関彼等の発見は，この重要なるェステルの 多くの製造者に非常に有用な子のとなろろ。

Jacobus Rinse は新らしいトール油誘導体, aluminium tritallate に関する諭文によつて \$250 の二等 賞を得た。それは薄膜を形成し，水分により固定され る。Rinse はそれを殆んど硬化する試薬として推蒿し， 非常に溶计易く, 殆んどの叙料物質と両存し得る事を 発見している。

Pauro Kajanne (フインランド)は, トール油脂肪 酸の生成変化を松の木が伐り倒されてから，トール油 が生ずる迄追跡した論文によって\$100の三等賞を獲 得した。

その他の意義ある論文が投稿され, 三つの最優秀論 文に加 らるに, 多くのこれらの論文の発行が準備され ている。(協会, 香川) 